\title{
Metoda Unit Selection Synthesizer dalam Pembuatan Synthesizer Suara Suling Recorder
}

\author{
M. ICHWAN, MILDA GUSTIANA, ARIEF SYAFIUDIN \\ Jurusan Teknik Informatika. Fakultas Teknologi Industri \\ Institut Teknologi Nasional Bandung \\ Email: ichwan@itenas.ac.id
}

\begin{abstract}
ABSTRAK
Unit Selection Synthesizer didasarkan pada penggabungan segmen-segmen dari sinyal suara yang sudah direkam oleh alat synthesizer. Selama proses sintesis, menggunakan algoritma The Hunt and Black yang memilih salah satu unit dari beberapa pilihan dalam menemukan barisan unit yang memenuhi spesifikasi yang dikehendaki. Berdasarkan penelitan synthesizer dapat digunakan untuk pembuatan suara suling recorder yang berjenis soprano dan mempunyai nada dasar G. Dari hasil perhitungan frekuensi nada dasar diperoleh nilai selisih frekuensi yang paling terkecil dimiliki oleh nada dasar La yaitu 11,875 Hz dan nilai selisih frekuensi yang paling terbesar dimiliki oleh nada dasar Do' yaitu $304,375 \mathrm{~Hz}$, sehingga didalam pengujian untuk synthesizer suling recorder digunakan nada dasar "La" sebagai nada dasar utama karena memiliki selisih terkecil dan hasil perhitungan frekuensi nada dasar "La" mendekati frekuensi asli dari nada dasar $G$.
\end{abstract}

Kata Kunci: Synthesizer, unit selection synthesizer, the hunt and black algorithm, suling recorder

\begin{abstract}
Unit Selection Synthesizer is based on the incorporation of segments of recorded sound signal from synthesizer. During the synthesis process, uses an algorithm The Hunt and Black that chooses one of the units of the few options in finding the line unit that meets the desired specifications. Based on research, synthesizer can be used to create the sound of recorder flute known as soprano flute that has a basic tone $G$. From the calculation frequency of the fundamental tone obtained by the differences of the frequency that the smallest owned by the basic tone $\mathrm{La}$ is $11,875 \mathrm{~Hz}$ and the differences of the frequency that the largest owned by the basic tone Do' is $304,375 \mathrm{~Hz}$, so that in testing for the synthesizer of flute uses basic tone "La" as The main fundamental tone and the results of the frequency calculation basic tone of "La" approaches the original frequency of the fundamental tone $G$.
\end{abstract}

Keywords: Synthesizer, unit selection synthesizer, the hunt and black algorithm, flute 


\section{Pendahuluan}

Synthesizer adalah sebuah perangkat elektronik yang memproduksi suara dalam bentuk sinyal suara (disebut juga gelombang suara) dan mengirimkannya kepada pembangkit suara. Alat ini juga memungkinkan penggunanya untuk mengganti karakteristik suara seperti tinggirendahnya nada, warna suara, dan volume suara.

Unit Selection Synthesizer merupakan teknik sintesis yang dominan digunakan dalam TTS. Teknik ini digunakan untuk memodifikasi sebuah sinyal suara seminimal mungkin untuk dapat menghasilkan suara seperti suara aslinya. Modifikasi yang dilakukan yaitu dengan cara The Hunt and Black Algorithm. The Hunt and Black Algorithm adalah sebuah algoritma modifikasi untuk menemukan kondisi yang terbaik dengan menggunakan berbagai parameter yang didapat dalam sinyal suara.

Suling recorder adalah sebuah alat musik alternatif yang dapat menghasilkan nada dengan cara ditiup. Suling recorder mudah digunakan dan dapat diperoleh dengan harga yang sangat terjangkau. Dengan menggunakan speech synthesizer untuk membuat suara suling recorder diharapkan dapat membuat suling recorder menjadi lebih modern, menarik, dan mudah digunakan.

\section{METODOLOGI PENELITIAN}

\subsection{Nada Dasar}

Nada merupakan unsur yang utama dalam sebuah musik didasarkan pada nada A dengan frekuensi $440 \mathrm{~Hz}$ [2]. Untuk frekuensi nada-nada yang lain dihitung menggunakan Persamaan (1) berikut:

$$
f=f_{0} * 2^{\frac{n}{12}} H z
$$

Dimana :

$\mathrm{f}=$ Frekuensi dari nada-nada yang lain

$\mathrm{f}_{0}=$ Ketentuan nilai untuk nada dasar $\mathrm{A}$

$\mathrm{n}$ = Langkah (oktaf) dari nada-nada yang akan di cari.

Tabel 1. Nada Dasar dan Oktaf

\begin{tabular}{|l|l|}
\hline Suara Nada & \multicolumn{1}{|c|}{ Nilai Langkah Oktaf } \\
\hline (n)
\end{tabular}

Berikut ini adalah nada-nada dasar berdasarkan frekuensi nada dan oktaf nada yang telah diakui secara internasional. 
Tabel 2. Frekuensi Nada C dan D

\begin{tabular}{|l|l|l|}
\hline \multirow{2}{*}{ Oktaf } & \multicolumn{3}{|c|}{ Frekuensi Nada (Hz) } \\
\cline { 2 - 4 } & \multicolumn{1}{|c|}{ C } & 36.708 \\
\hline $1(\mathrm{C})$ & 32.703 & 73.416 \\
\hline $2(\mathrm{D})$ & 65.406 & 146.83 \\
\hline $3(\mathrm{E})$ & 130.87 & 293.66 \\
\hline $4(\mathrm{~F})$ & 261.63 & 587.33 \\
\hline $5(\mathrm{G})$ & 523.25 & 1174.7 \\
\hline $6(\mathrm{~A})$ & 1046.5 & 2349.3 \\
\hline $7(\mathrm{~B})$ & 2093 & \\
\hline
\end{tabular}

Tabel 3. Frekuensi Nada E dan $\mathbf{F}$

\begin{tabular}{|l|l|l|}
\hline \multirow{2}{*}{ Oktaf } & \multicolumn{3}{|c|}{ Frekuensi Nada (Hz) } \\
\cline { 2 - 4 } & \multicolumn{1}{|c|}{$\mathrm{E}$} & $\mathrm{F}$ \\
\hline $1(\mathrm{C})$ & 41.203 & 43.654 \\
\hline $2(\mathrm{D})$ & 82.407 & 87.307 \\
\hline $3(\mathrm{E})$ & 164.81 & 174.61 \\
\hline $4(\mathrm{~F})$ & 329.63 & 349.23 \\
\hline $5(\mathrm{G})$ & 659.26 & 698.46 \\
\hline $6(\mathrm{~A})$ & 1318.5 & 1396.9 \\
\hline $7(\mathrm{~B})$ & 2637 & 2793.8 \\
\hline
\end{tabular}

Tabel 4 Frekuensi Nada G, A, dan B

\begin{tabular}{|l|l|l|l|}
\hline \multirow{2}{*}{ Oktaf } & \multicolumn{3}{|c|}{ Frekuensi Nada (Hz) } \\
\cline { 2 - 4 } & \multicolumn{1}{|c|}{ G } & \multicolumn{1}{|c|}{ A } & \multicolumn{1}{|c|}{ B } \\
\hline $1(\mathrm{C})$ & 48.999 & 55 & 61.735 \\
\hline $2(\mathrm{D})$ & 97.999 & 110 & 123.47 \\
\hline $3(\mathrm{E})$ & 196 & 220 & 246.94 \\
\hline $4(\mathrm{~F})$ & 392 & 440 & 493.88 \\
\hline $5(\mathrm{G})$ & 783.99 & 880 & 987.77 \\
\hline $6(\mathrm{~A})$ & 1568 & 1760 & 1975.5 \\
\hline $7(\mathrm{~B})$ & 3136 & 3520 & 3951.1 \\
\hline
\end{tabular}

\subsection{Unit Selection Synthesizer}

Unit selection synthesizer adalah resequencing algorithm yang melakukan pembagian dalam speech kemudian mengaturnya kembali. Cara pandang unit selection dengan cara ini dikenal sebagai prinsip modifikasi terkecil (principle of least modification). Prinsip ini menjelaskan bahwa kealamian dari origina/basis data sudah tentu sempurna, dan modifikasi apapun yang dilakukan, baik itu trimming, joining, atau menggunakan signal processing akan menghasilkan risiko kerusakan pada data suara yang asli. Sehingga menghasilkan spesifikasi yang diinginkan dengan cara mengatur kembali data original sedikit mungkin sampai menghasilkan kualitas suara yang mirip dengan data yang asli [7].

\subsection{The Hunt and Black Algorithm}

Salah satu cara untuk mengatasi permasalahan modifikasi terkecil diatas adalah dengan menggunakan algoritma yang telah dikembangkan oleh Andrew Hunt dan Alan W. Black. Dalam kerangka kerja Hunt and Black, unit selection didefinisikan sebagai sebuah pencarian melalui semua unit yang memungkinkan untuk menemukan kemungkinan barisan unit yang terbaik. Parameter yang dipakai untuk perhitungan tersebut dapat bermacam-macam, seperti pitch, frekuensi, durasi, MFCC (Mel-Frequency Cepstral Coefficient), daya signal, dan property dari signal ucapan lainnya [1]. 


\subsection{Fast Fourier Transform (FFT)}

Suatu sinyal didefinisikan sebagai besaran fisik yang berubah-ubah menurut waktu, ruang, atau variabel-variabel lainnya. Sinyal dapat dianalisis dari dua perbedaan sudut pandang dan sinyal dapat direpresentasi dalam kedua domain, yaitu domain frekuensi dan domain waktu. Untuk mengenali sinyal dari domain yang satu ke domain lainnya digunakan Fourier Transform [3].

FFT digunakan untuk mengubah sinyal dalam domain waktu menjadi domain frekuensi supaya sinyal yang bersifat analog tersebut dapat dibaca frekuensinya dan dapat diolah dalam bentuk digital. Proses FFT dapat dilihat dalam Persamaan (2) sebagai berikut:

$$
f(n)=\sum_{K=0}^{N-1} y_{k} e^{-\frac{2 \pi j k n}{N}}, n=0,1, ., N-1
$$

Dengan:

$$
\begin{array}{ll}
f(n) & =\text { frekuensi } \\
k & =0,1,2, \ldots, \mathrm{N}-1 \\
\mathrm{~N} & =\text { jumlah sample pada masing-masing frame } \\
j & =\text { bilangan imajiner }(\sqrt{ }-1) \\
\mathrm{n} & =1,2,3, \ldots(\mathrm{N}-1)
\end{array}
$$

\subsection{Perancangan Sistem}

Prosedur dari aplikasi suling recorder synthesizer ini dibuat sebuah model kerja sistem aplikasi secara umum seperti pada Gambar 1.

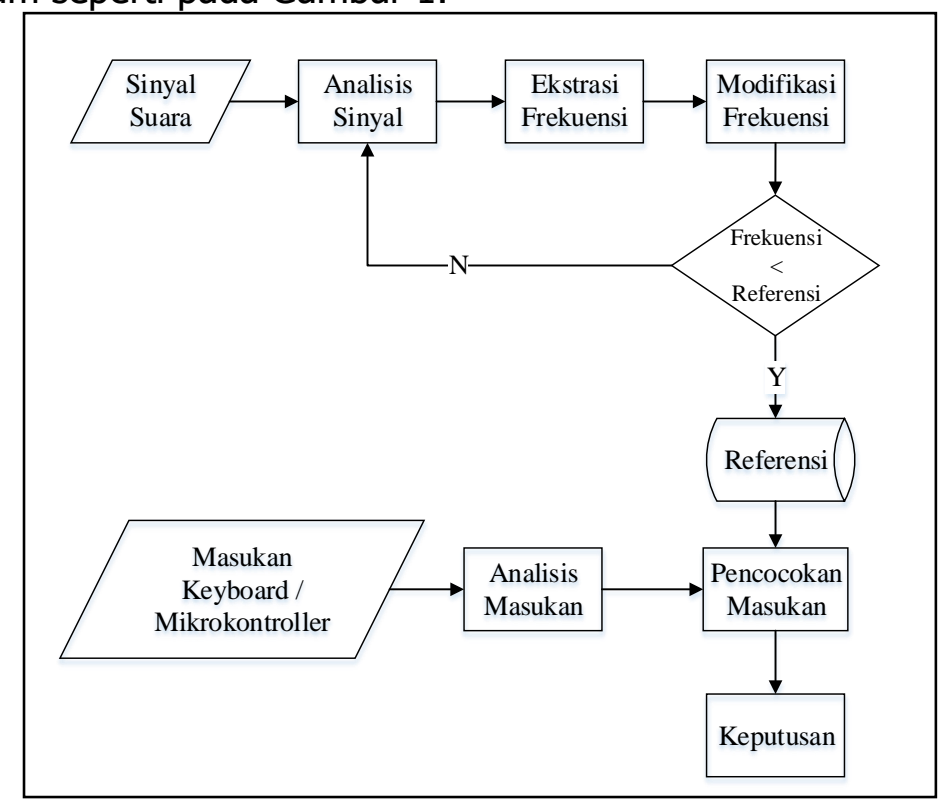

\section{Gambar 1. Gambaran Sistem Kerja Aplikasi Speech Synthesizer}

Langkah pertama dalam aplikasi yaitu mengambil sinyal suara yang sebelumnya telah direkam dalam format .wav. Perekaman suara dilakukan sebanyak 8 kali sesuai dengan jumlah nada dasar suling recorder yaitu do, re, mi, fa, so, la, si, dan do'.

Sinyal suara yang telah direkam kemudian diubah menjadi sebuah grafik yang menunjukan lamanya waktu perekaman dan besar amplitudo dari sebuah sinyal suara. 
Perubahan sinyal suara dilakukan dengan menggunakan fungsi plot pada Matlab untuk menggambarkan sebuah grafik dari sinyal suara.

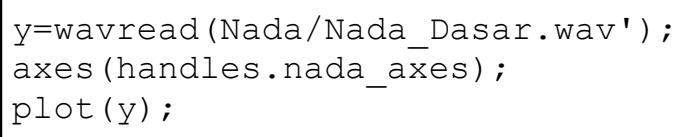

Aplikasi akan membaca sinyal suara yang dipilih oleh pengguna, kemudian aplikasi memilih axes yang akan digunakan sebagai grafik. Perintah plot digunakan sebagai perintah untuk menggambarkan grafik ke dalam axes, sehingga akan terbentuk sebuah grafik sinyal suara.

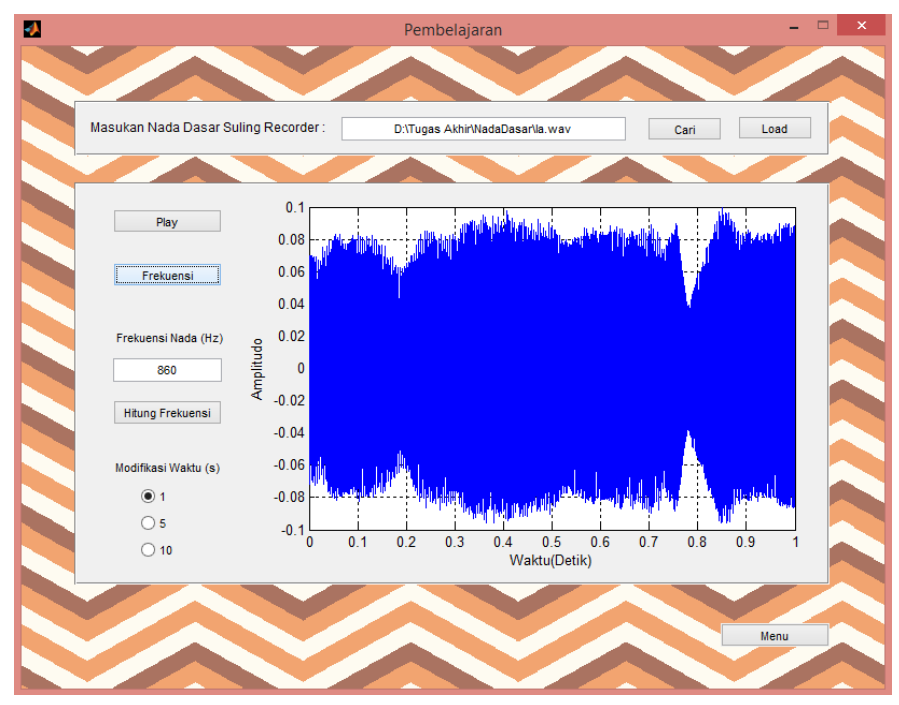

Gambar 2. Grafik sinyal suara

Setelah diubah kedalam bentuk grafik langkah selanjutnya adalah melakukan ekstraksi frekuensi pada sebuah sinyal suara untuk memperoleh nilai frekuensi yang nantinya akan dimodifikasi dan disimpan sebagai basis data.

Nilai frekuensi diperoleh dengan cara menghitung jumlah sampel masing-masing frame dan menambahkan bilangan imajiner $(\sqrt{ }-1)$. Frekuensi diperoleh dengan cara mengambil nilai tertinggi dari sebuah grafik frekuensi sinyal suara.

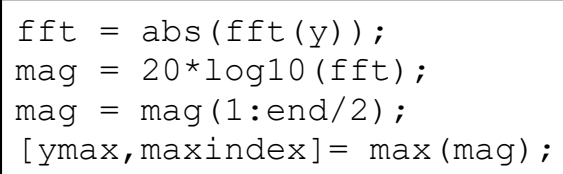

Ekstraksi frekuensi dilakukan dengan menggunakan fungsi fast fourier tranform (fft) pada Matlab. Aplikasi akan mengubah sinyal suara dengan fungsi fft menjadi nilai absolut fft dan grafik frekuensi, kemudian nilai absolut yang dihasilkan akan diubah menjadi besaran desibel untuk mengambil nilai frekuensi dasar yang akan dihitung untuk mendapatkan frekuensi nada dasar. 
Gambar 3. Nilai Frekuensi Sinyal Suara

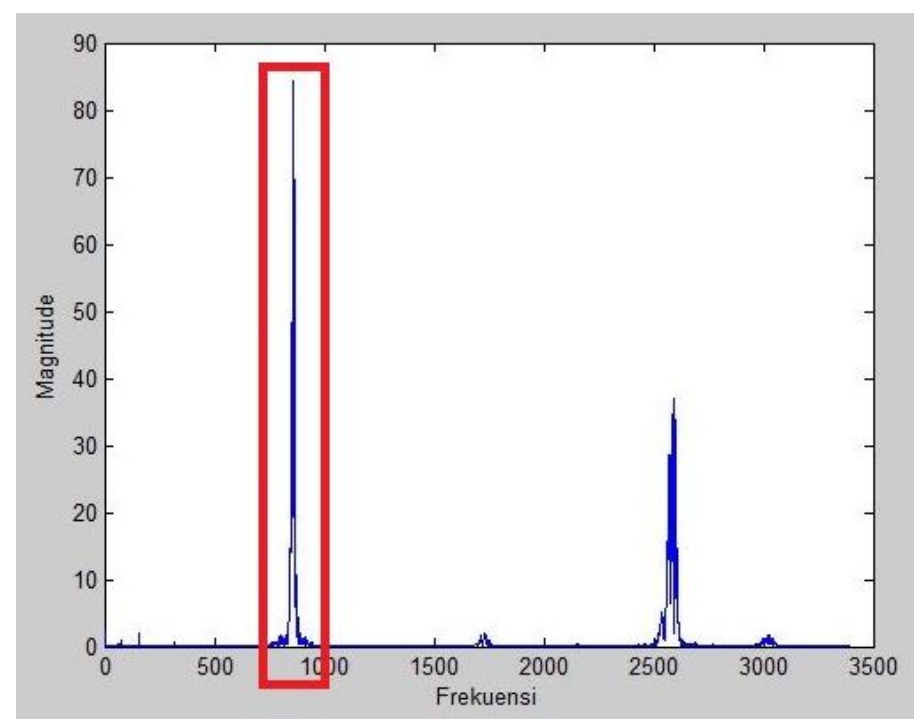

Gambar 4. Grafik Frekuensi Sinyal Suara

Perhitungan frekuensi dilakukan untuk menemukan frekuensi nada-nada yang didasarkan pada sebuah nada. Perhitungan diperoleh dengan menggunakan rumus frekuensi nada dasar (rumus 1) yaitu mengalikan frekuensi dasar dengan langkah oktaf pada nada dasar sehingga akan menghasilkan 8 buah frekuensi untuk nada-nada dasar.

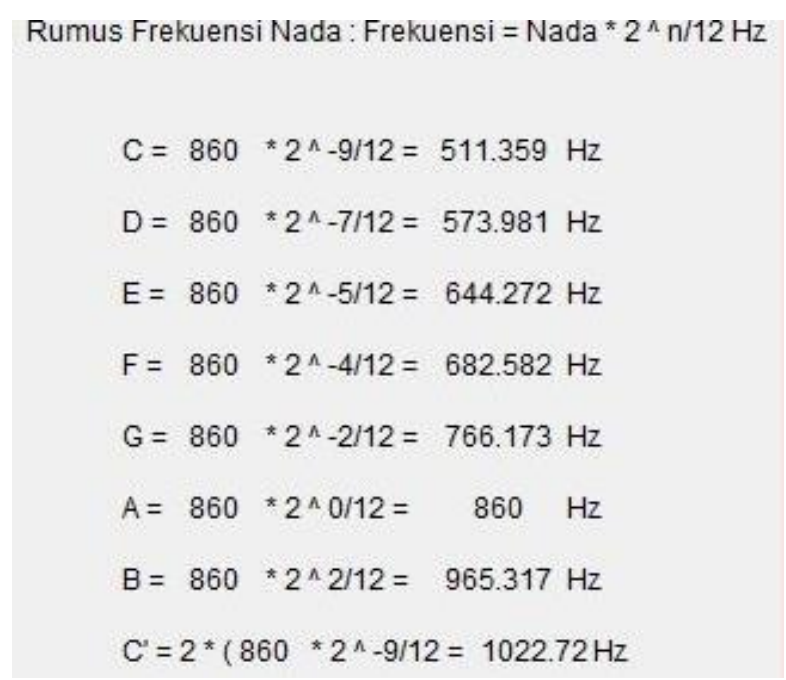

Gambar 5. Perhitungan Frekuensi

Proses modifikasi dilakukan dengan cara memberikan panjang waktu untuk 8 buah frekuensi. Modifikasi waktu yang terdapat dalam aplikasi yaitu 1 detik, 5 detik, dan 10 detik. Pengguna dapat memilih salah satu panjang waktu yang akan dijadikan suara nada dasar. 


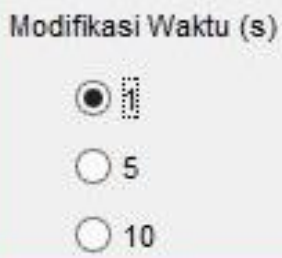

\section{Gambar 6. Modifikasi Waktu}

Sebelum disimpan kedalam referensi basis data akan dilakukan tahapan untuk seleksi nada. Seleksi nada dilakukan dengan cara membandingkan selisih frekuensi nada dasar yang ada pada referensi dengan selisih frekuensi nada dasar yang akan dibuat untuk referensi. Total selisih yang terkecil akan dijadikan sebagai referensi nada basis data.

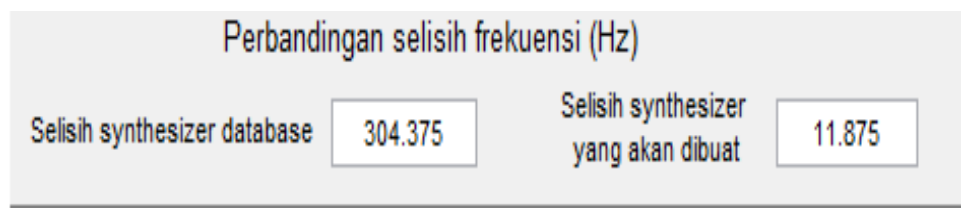

Gambar 7. Perbandingan Selisih Frekuensi Nada

Setelah mendapatkan referensi nada dasar, kemudian dapat dilakukan permainan nada. Permainan nada dapat dilakukan dengan cara memberikan masukan oleh pengguna dan aplikasi akan memproses masukan dan mencocokan dengan referensi nada.

Masukan data diperoleh melalui keyboard dan mikrokontroller. Masukan data dengan menggunakan keyboard dilakukan dengan cara menekan tombol-tombol yang telah diatur dalam aplikasi, misalkan untuk memainkan nada do pengguna harus menekan tombol 1.

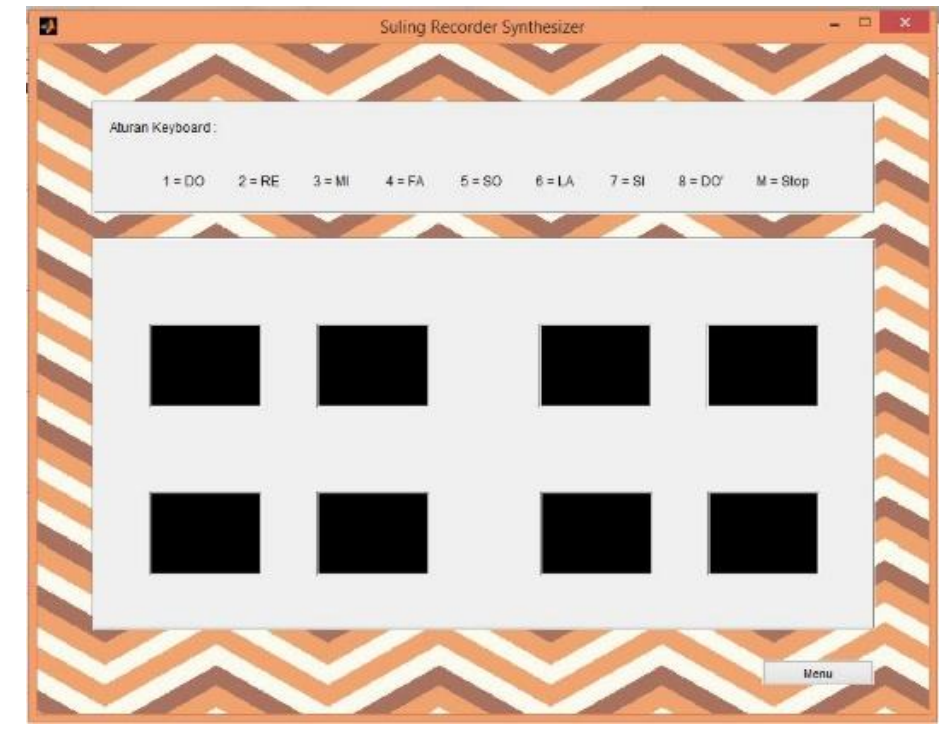

Gambar 8. Masukan Data Melalui Keyboard

Masukan data menggunakan mikrokontroller dilakukan dengan cara memutar potensiometer, nilai yang diperoleh akan memainkan nada tertentu sesuai dengan nilai yang diperoleh. Misalkan untuk memainkan nada do pengguna harus memutar potensio ke arah tulisan do. 


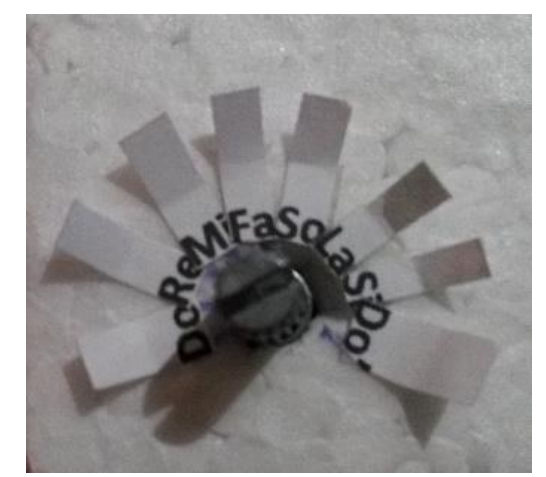

Gambar 9. Masukan data melalui mikrokontroller

Analisis masukan dilakukan dengan cara pembacaan tombol yang dilakukan oleh pengguna jika menggunakan keyboard sebagai masukan dan pembacaan nilai potensiometer yang dilakukan oleh pengguna jika menggunakan mikrokontroller.

Pencocokan data dilakukan dengan cara mencocokan masukan nada dengan aturan pada aplikasi dan aturan pada aplikasi akan memainkan nada yang ada pada referensi basis data sesuai masukan data yang telah sesuai.

Pada proses pencocokan mikrokontroller, mikrokontroller akan memberitahukan hasil masukan dengan cara menyalakan led sesuai nada yang diberikan oleh pengguna.

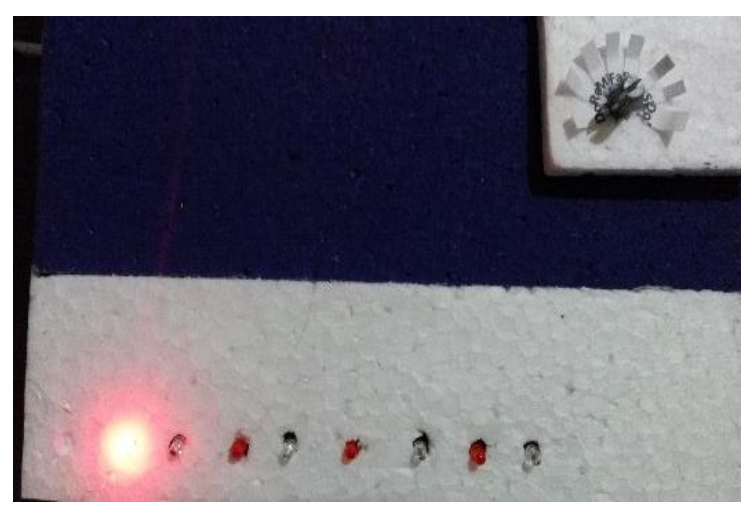

Gambar 10. Analisis dan Pencocokan Masukan menggunakan Mikrokontroller

Pada proses pencocokan keyboard, aplikasi akan memberitahukan hasil masukan dengan cara mengganti kotak hitam menjadi putih dengan tulisan sesuai nada yang diberikan oleh pengguna. 


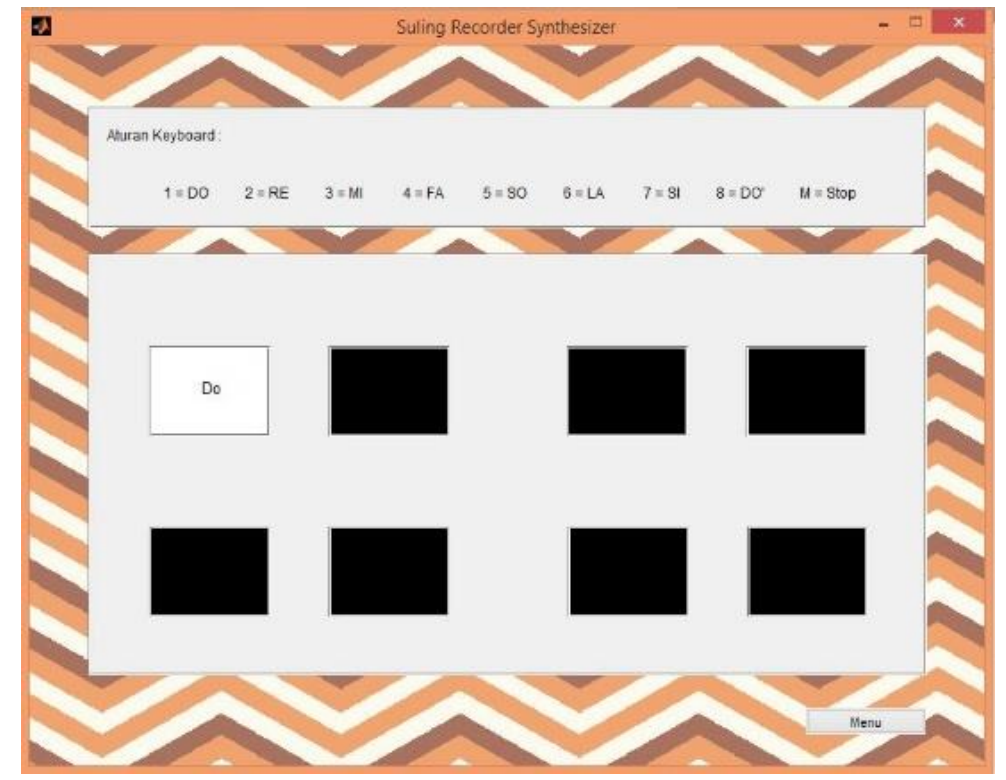

Gambar 11. Analisis dan Pencocokan masukan menggunakan keyboard

\subsubsection{Unit Selection Synthesizer}

Tahapan-tahapan yang digunakan dalam proses unit selection synthesizer terdapat pada Gambar 12. Langkah pertama adalah pengambilan data sinyal suara nada dasar suling recorder yaitu nada do, re, mi, fa, so, la, si, dan do'. Kemudian sinyal suara diekstraksi dengan fast fourier transform untuk mendapatkan nilai frekuensi dari sinyal suara, misalnya pada nada dasar do mempunyai nilai frekuensi $526 \mathrm{~Hz}$.

Nilai frekuensi yang diperoleh akan dilakukan perhitungan frekuensi nada dasar untuk memperoleh delapan nada dasar dengan Persamaan (1) frekuensi nada dasar. Misalkan untuk mendapatkan nilai do dari perhitungan frekuensi dengan nada dasar do sebagai nada dasar acuan, yaitu:

$$
\begin{aligned}
& f=f_{0} * 2^{\frac{n}{12}} H z=526 * 2^{\frac{-9}{12}} \\
& f=313 H z
\end{aligned}
$$

Sehingga dapat diketahui nilai frekuensi do dari nada dasar acuan do yaitu sebesar $313 \mathrm{~Hz}$. Setelah diketahui delapan frekuensi nada dasar, kemudian dilakukan modifikasi waktu sebagai panjang suara nada. Panjang waktu dapat dipilih agar sesuai dengan suara nada asli, biasanya sekitar 5 detik dan 10 detik karena apabila terlalu panjang akan mengakibatkan ketidaksesuaian dengan suara nada asli.

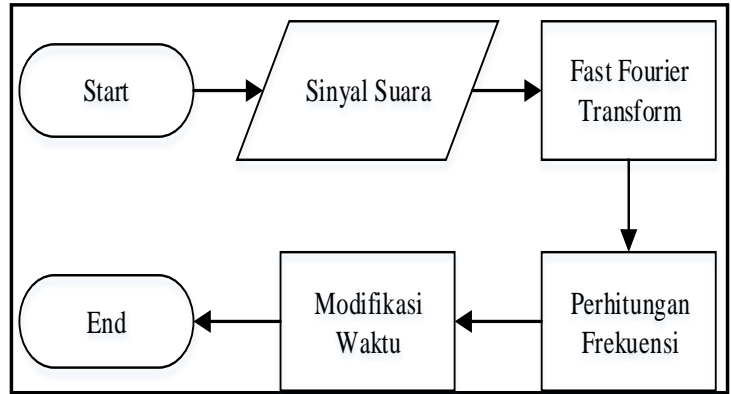

Gambar 12. Flowchart Unit Selection Synthesizer 


\subsubsection{Use Case Diagram}

Berdasarkan analisis sistem yang telah dilakukan, maka Suling Recorder Synthesizer memerlukan fungsi pembelajaran nada, modifikasi nada, dan permainan nada seperti diagram use case pada Gambar 13.

Fungsi pembelajaran nada adalah proses untuk mempelajari sebuah sinyal suara nada asli suling recorder menjadi sebuah nilai frekuensi yang akan dijadikan delapan nada dasar suling recorder pada synhtesizer. Fungsi modifikasi nada adalah proses dimana pengguna memodifikasi waktu pada frekuensi nada agar dapat sesuai dengan nada asli suling recorder. Fungsi permainan nada adalah proses akhir dimana pengguna dapat mencoba memainkan nada-nada yang telah dipelajari dan dimodifikasi dengan menggunakan keyboard atau mikrokontroller.

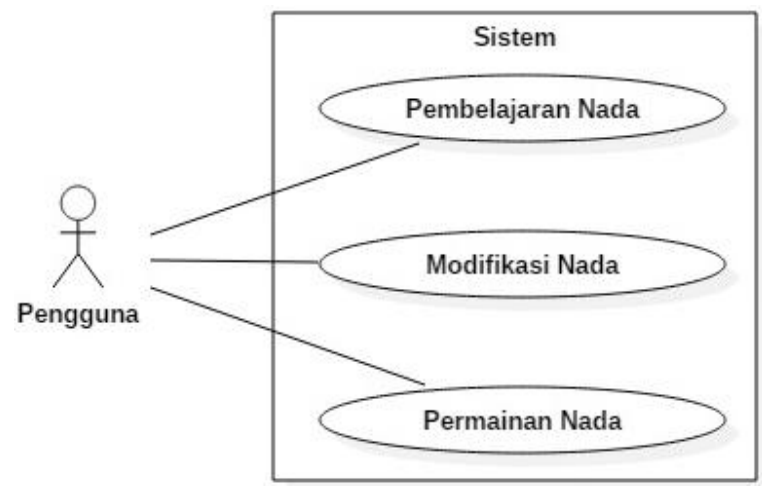

Gambar 13. Use Case Diagram Aplikasi Suling Recorder Synthesizer

\subsubsection{Sequence Diagram}

Sequence diagram digunakan untuk menggambarkan interaksi antar objek didalam dan disekitar sistem berupa message yang digambarkan terhadap waktu. Objek yang berinteraksi pada proses sistem suling recorder synthesizer yaitu Pengguna (user), kelas Suara Nada Dasar, kelas Unit Selection Synthesizer, dan kelas Permainan Nada seperti pada Gambar 14. 


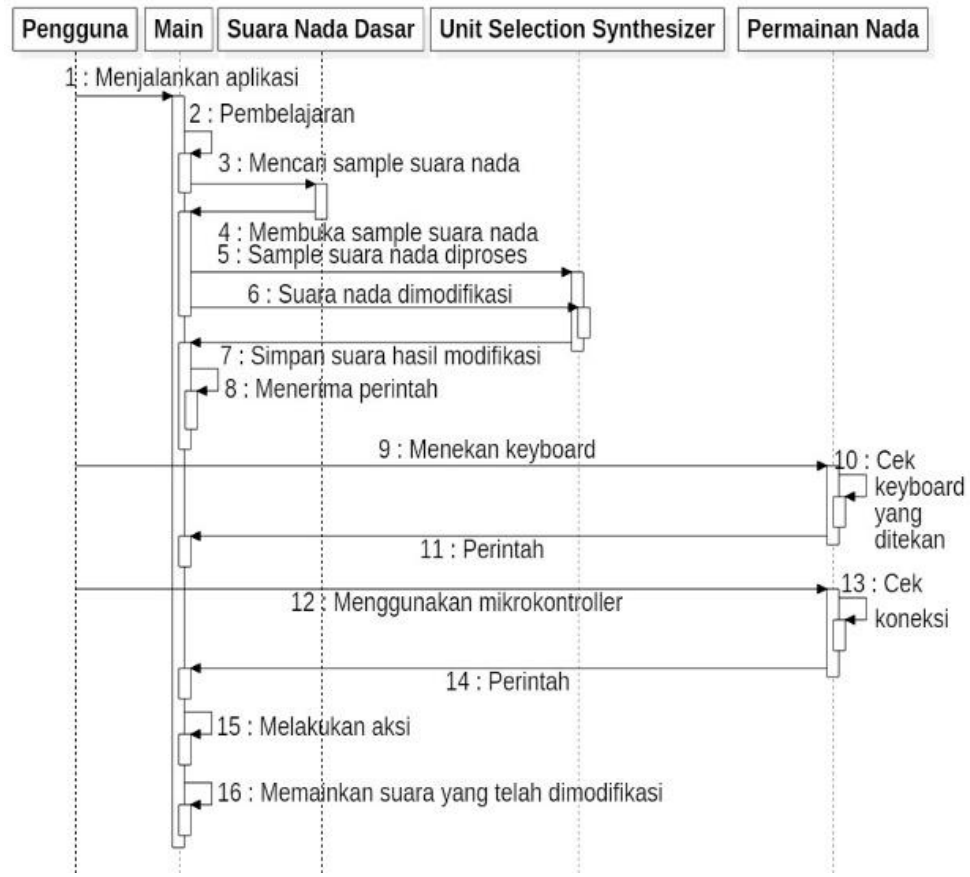

Gambar 14. Sequence Diagram

\subsubsection{Perancangan Suling Recorder Synthesizer}

Perangkat keras yang digunakan yaitu mikrokontroller Arduino Uno R3, potensiometer, dan led. Berikut adalah perancangan perangkat keras suling recorder synthesizer.

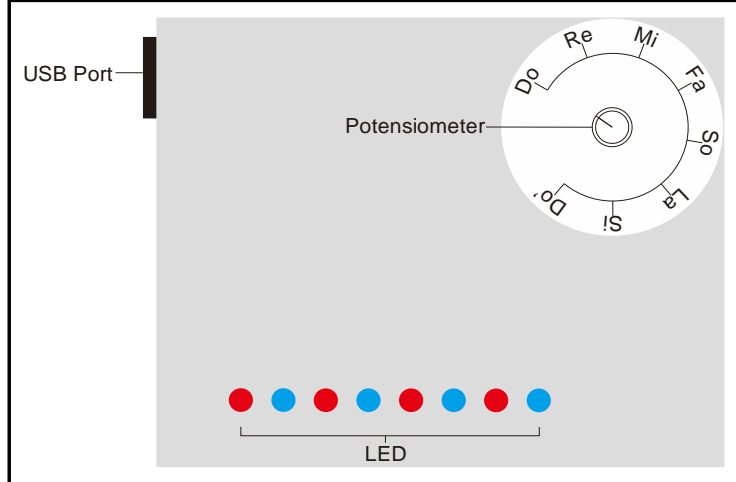

\section{Gambar 15. Suling Recorder SynthesizerTampak Atas}

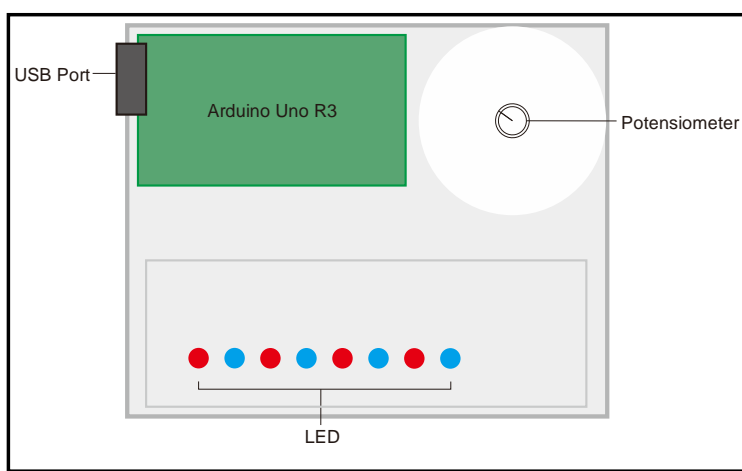

Gambar 16. Suling Recorder SynthesizerTampak Dalam 


\section{ANALISIS DAN PEMBAHASAN}

Di samping ini akan menunjukkan hasil pengujian aplikasi menggunakan suara nada acuan yang terdiri dari 8 nada yaitu do, re, mi, fa, so, la, si, dan do'. Pengujian dilakukan secara bertahap dimulai dari nada dasar yang terendah (do) sampai nada dasar tertinggi (do') dengan membandingkan frekuensi perhitungan dengan frekuensi asli, sehingga akan mendapatkan nilai selisih frekuensi.

Nilai selisih frekuensi terkecil dari total selisih pada masing-masing nada dasar akan dijadikan sebagai nada dasar acuan yang terbaik.

Tabel 5. Pengujian Nada Acuan Do

\begin{tabular}{|l|l|l|l|}
\hline $\begin{array}{l}\text { Nada } \\
\text { dasar }\end{array}$ & $\begin{array}{l}\text { Frekuensi } \\
\text { Synthesizer } \\
(\mathrm{Hz})\end{array}$ & $\begin{array}{l}\text { Frek Asli } \\
(\mathrm{Hz})\end{array}$ & $\begin{array}{l}\text { Selisih } \\
(\mathrm{Hz})\end{array}$ \\
\hline Do & 313 & 526 & 213 \\
\hline Re & 351 & 587 & 236 \\
\hline $\mathrm{Mi}$ & 394 & 658 & 264 \\
\hline Fa & 417 & 695 & 278 \\
\hline So & 469 & 779 & 310 \\
\hline La & 526 & 860 & 334 \\
\hline Si & 590 & 971 & 381 \\
\hline Do' $^{\prime}$ & 626 & 1045 & 419 \\
\hline
\end{tabular}

Tabel 7. Pengujian Nada Acuan Mi

\begin{tabular}{|l|l|l|l|}
\hline $\begin{array}{l}\text { Nada } \\
\text { dasar }\end{array}$ & $\begin{array}{l}\text { Frekuensi } \\
\text { Synthesizer } \\
(\mathrm{Hz})\end{array}$ & $\begin{array}{l}\text { Frek Asli } \\
(\mathrm{Hz})\end{array}$ & $\begin{array}{l}\text { Selisih } \\
(\mathrm{Hz})\end{array}$ \\
\hline Do & 391 & 526 & 135 \\
\hline Re & 439 & 587 & 148 \\
\hline $\mathrm{Mi}$ & 493 & 658 & 165 \\
\hline Fa & 522 & 695 & 173 \\
\hline So & 586 & 779 & 193 \\
\hline La & 658 & 860 & 202 \\
\hline Si & 739 & 971 & 232 \\
\hline Do $^{\prime}$ & 782 & 1045 & 263 \\
\hline
\end{tabular}

Tabel 9. Pengujian Nada Acuan So

\begin{tabular}{|l|l|l|l|}
\hline $\begin{array}{l}\text { Nada } \\
\text { dasar }\end{array}$ & $\begin{array}{l}\text { Frekuensi } \\
\text { Synthesizer } \\
(\mathrm{Hz})\end{array}$ & $\begin{array}{l}\text { Frek Asli } \\
(\mathrm{Hz})\end{array}$ & $\begin{array}{l}\text { Selisih } \\
(\mathrm{Hz})\end{array}$ \\
\hline $\mathrm{Do}$ & 463 & 526 & 63 \\
\hline $\mathrm{Re}$ & 520 & 587 & 67 \\
\hline $\mathrm{Mi}$ & 584 & 658 & 74 \\
\hline $\mathrm{Fa}$ & 618 & 695 & 77 \\
\hline So & 694 & 779 & 85 \\
\hline $\mathrm{La}$ & 779 & 860 & 81 \\
\hline Si $^{\prime}$ & 874 & 971 & 97 \\
\hline Do' $^{\prime}$ & 926 & 1045 & 119 \\
\hline
\end{tabular}

Tabel 6. Pengujian nada acuan $\mathbf{R e}$

\begin{tabular}{|l|l|l|l|}
\hline $\begin{array}{l}\text { Nada } \\
\text { dasar }\end{array}$ & $\begin{array}{l}\text { Frekuensi } \\
\text { Synthesizer } \\
(\mathrm{Hz})\end{array}$ & $\begin{array}{l}\text { Frek Asli } \\
(\mathrm{Hz})\end{array}$ & $\begin{array}{l}\text { Selisih } \\
(\mathrm{Hz})\end{array}$ \\
\hline Do & 349 & 526 & 177 \\
\hline Re & 392 & 587 & 195 \\
\hline $\mathrm{Mi}$ & 440 & 658 & 218 \\
\hline Fa & 466 & 695 & 229 \\
\hline So & 523 & 779 & 256 \\
\hline La & 587 & 860 & 273 \\
\hline Si & 659 & 971 & 312 \\
\hline Do' $^{\prime}$ & 698 & 1045 & 347 \\
\hline
\end{tabular}

Tabel 8. Pengujian Nada Acuan Fa

\begin{tabular}{|l|l|l|l|}
\hline $\begin{array}{l}\text { Nada } \\
\text { dasar }\end{array}$ & $\begin{array}{l}\text { Frekuensi } \\
\text { Synthesizer } \\
(\mathrm{Hz})\end{array}$ & $\begin{array}{l}\text { Frek Asli } \\
(\mathrm{Hz})\end{array}$ & $\begin{array}{l}\text { Selisih } \\
(\mathrm{Hz})\end{array}$ \\
\hline $\mathrm{Do}$ & 413 & 526 & 113 \\
\hline $\mathrm{Re}$ & 464 & 587 & 123 \\
\hline $\mathrm{Mi}$ & 521 & 658 & 137 \\
\hline $\mathrm{Fa}$ & 552 & 695 & 143 \\
\hline $\mathrm{So}$ & 619 & 779 & 160 \\
\hline $\mathrm{La}$ & 695 & 860 & 165 \\
\hline $\mathrm{Si}$ & 780 & 971 & 191 \\
\hline $\mathrm{Do}^{\prime}$ & 826 & 1045 & 219 \\
\hline
\end{tabular}

Tabel 10. Pengujian Nada Acuan La

\begin{tabular}{|l|l|l|l|}
\hline $\begin{array}{l}\text { Nada } \\
\text { dasar }\end{array}$ & $\begin{array}{l}\text { Frekuensi } \\
\text { Synthesizer } \\
(\mathrm{Hz})\end{array}$ & $\begin{array}{l}\text { Frek Asli } \\
(\mathrm{Hz})\end{array}$ & $\begin{array}{l}\text { Selisih } \\
(\mathrm{Hz})\end{array}$ \\
\hline $\mathrm{Do}$ & 511 & 526 & 15 \\
\hline $\mathrm{Re}$ & 574 & 587 & 13 \\
\hline $\mathrm{Mi}$ & 644 & 658 & 14 \\
\hline $\mathrm{Fa}$ & 683 & 695 & 12 \\
\hline $\mathrm{So}$ & 766 & 779 & 13 \\
\hline $\mathrm{La}$ & 860 & 860 & 0 \\
\hline Si $^{\prime}$ & 965 & 971 & 6 \\
\hline Do $^{\prime}$ & 1023 & 1045 & 22 \\
\hline
\end{tabular}


Tabel 11. Pengujian Nada Acuan Si

\begin{tabular}{|l|l|l|l|}
\hline $\begin{array}{l}\text { Nada } \\
\text { dasar }\end{array}$ & $\begin{array}{l}\text { Frekuensi } \\
\text { Synthesizer } \\
(\mathrm{Hz})\end{array}$ & $\begin{array}{l}\text { Frek Asli } \\
(\mathrm{Hz})\end{array}$ & $\begin{array}{l}\text { Selisih } \\
(\mathrm{Hz})\end{array}$ \\
\hline Do & 577 & 526 & 51 \\
\hline Re & 648 & 587 & 61 \\
\hline $\mathrm{Mi}$ & 727 & 658 & 69 \\
\hline Fa & 771 & 695 & 76 \\
\hline So & 865 & 779 & 86 \\
\hline La & 971 & 860 & 111 \\
\hline Si & 1090 & 971 & 119 \\
\hline Do $^{\prime}$ & 1158 & 1045 & 113 \\
\hline
\end{tabular}

Tabel 12. Pengujian Nada Acuan Do'

\begin{tabular}{|l|l|l|l|}
\hline $\begin{array}{l}\text { Nada } \\
\text { dasar }\end{array}$ & $\begin{array}{l}\text { Frekuensi } \\
\text { Synthesizer } \\
(\mathrm{Hz})\end{array}$ & $\begin{array}{l}\text { Frek Asli } \\
(\mathrm{Hz})\end{array}$ & $\begin{array}{l}\text { Selisih } \\
(\mathrm{Hz})\end{array}$ \\
\hline Do & 621 & 526 & 95 \\
\hline $\mathrm{Re}$ & 697 & 587 & 110 \\
\hline $\mathrm{Mi}$ & 783 & 658 & 125 \\
\hline Fa & 829 & 695 & 134 \\
\hline So & 931 & 779 & 152 \\
\hline La & 1045 & 860 & 185 \\
\hline Si & 1173 & 971 & 202 \\
\hline Do' $^{\prime}$ & 1243 & 1045 & 198 \\
\hline
\end{tabular}

\subsection{Nilai Rata-Rata Selisih dari Hasil Pengujian}

Nilai dari pengujian memiliki hasil yang berbeda-beda, yaitu sebagai berikut:

1. Nada Do

Selisih 213, 236, 264, 278, 310, 334, 381, 419, maka rata-rata selisihnya adalah 304.375

2. Nada Re

Selisih 177, 195, 218, 229, 256, 273, 312, 347, maka rata-rata selisihnya adalah 250.875

3. Nada Mi

Selisih 135, 148, 165, 173, 193, 202, 232, 263, maka rata-rata selisihnya adalah 188.875

4. Nada Fa

Selisih 113, 123, 137, 143, 160, 165, 191, 219, maka rata-rata selisihnya adalah 156.375

5. Nada So

Selisih $63,67,74,77,85,81,97,119$, maka rata-rata selisihnya adalah 82.875

6. Nada La

Selisih $15,13,14,12,13,0,6,22$, maka rata-rata selisihnya adalah 11.875

7. Nada $\mathrm{Si}$

Selisih $51,61,69,76,86,111,119,113$, maka rata-rata selisihnya adalah 85.75

8. Nada Do'

Selisih 95, 110, 125, 134, 152, 185, 202, 198, maka rata-rata selisihnya adalah 150.125

\section{KESIMPULAN}

Penelitian yang dilakukan pada tugas akhir ini menghasilkan beberapa kesimpulan sebagai berikut:

1. Pengembangan sistem speech synthesizer untuk suara suling recorder sudah dapat berjalan sesuai dengan yang diinginkan.

2. Dari hasil perhitungan yang dilakukan dengan persamaan(1), hasil selisih frekuensi synthesizer memiliki nilai yang berbeda-beda. Nilai selisih frekuensi yang paling terkecil dimiliki oleh nada dasar La yaitu $11,875 \mathrm{~Hz}$ dan nilai selisih frekuensi yang paling terbesar dimiliki oleh nada dasar Do' yaitu $304,375 \mathrm{~Hz}$.

3. Dari hasil pengujian yang dilakukan sebanyak 8 nada dasar untuk 8 nada dasar synthesizer, nada dasar "La" merupakan nada dasar yang memiliki selisih terkecil 
diantara nada dasar lainnya dan dapat menjadi suara nada acuan yang terbaik untuk menentukan nada-nada dasar synthesizer.

4. Dapat diketahui dari hasil penelitian bahwa jenis suling recorder soprano yang digunakan memiliki nilai Oktaf 5 (nada dasar G).

\section{DAFTAR RUJUKAN}

[1] Taylor, Paul. "Text-to-Speech Synthesis".United Kingdom:Cambridge University Press.

[2] A. Fikri Akbar Hofa.2012.Menghitung Nilai Frekuensi Nada-Nada. http://afikriakbarhofa.blogspot.com/2012/02/menghitung-nilai-frekuensi-nadanada.html, (diakses 20 April 2015).

[3] Dutoit, T."A Short Introduction to Text-to-Speech Synthesis". Diunduh dari:http://www2.research.att.com/ ttsweb/tts/papers/2005_EEHandbook/tts.pdf, (diakses 20 April 2015)

[4] Iwan Iwut Tritoasmoro.2010.Text-to-Speech Bahasa Indonesia Menggunakan Concatenative Synthesizer Berbasis Fonem.Bandung.Sekolah Tinggi Teknologi Telkom Bandung.

[5] Sigit Wasista dan Novita Astin.2010. Algoritma Sistem Pembaca Text Bahasa Indonesia Menggunakan Metode FSA (Finite State Automata).Surabaya.Institut Teknologi Sepuluh Nopember.

[6] Pande Made Mahendri Pramadewi dan Made Windu Antara Kesiman.2013. Pengembangan Aplikasi Text do Speech untuk Bahasa Bali.Bali.Universitas Pendidikan Ganesha.

[7] Anneahira. Synthesizer - Alat Produksi Suara Elektronik Serba Bisa.http://www.anneahira.com/synthesizer.htm, (diakses 1 Desember 2015). 